\title{
PENGARUH KUALITAS PRODUK TERHADAP KEPUTUSAN PEMBELIAN KENDARAAN BERMOTOR YAMAHA MIO PADA CV. ROLYA MOTOR DI BANDAR LAMPUNG
}

\author{
$\operatorname{Kuswarak}^{(1)}$ \\ Fakultas Ekonomi Universitas Sang Bumi Ruwa Jurai \\ kuswarak@fe.saburai.ac.id
}

\begin{abstract}
Abstrak. Ketatnya persaingan dalam dunia usaha menuntut setiap perusahaan untuk mengambil langkahlangkah dan strategi yang tepat guna memenangkan persaingan dengan kompetitor demi menjaga eksistensi yang dimiliki perusahaan berpengaruh terhadap keputusan pembelian kendaraan bermotor Yamaha Mio pada dan tentunya mempertahankan bahkan meningkatkan keuntungan atau profit yang dihasilkan. Berdasarkan hasil Uji t didapat nilai $t$ hitung $=12,060$ dan setelah dibandingkan dengan $\mathrm{t}$ tabel pada taraf signifikan $95 \%$ yaitu 1,73 , maka $\mathrm{t}$ hitung $=12,060>\mathrm{t}$ tabel $=1,73$ sehingga dapat disimpulkan bahwa $:$ Ha yang menyatakan terdapat pengaruh antara variabel Kualitas Produk $(\mathrm{X})$ terhadap Keputusan Pembelian (Y) dapat diterima. Jadi variabel Kualitas Produk (X) berpengaruh terhadap variabel Keputusan Pembelian (Y). Kemudian pada persamaan regresi antara variabel Kualitas Produk (X) terhadap variabel Keputusan Pembelian $(\mathrm{Y})$ adalah $\mathrm{Y}=0,758+0,974 \mathrm{X}$ penjelasannya adalah : bo $=0,758$ merupakan nilai konstanta atau yang dapat diartikan bahwa Kualitas Produk bernilai konstan sebesar satu point, berakibat keputusan pembelian akan meningkat sebesar $0,758 \% . \quad \mathrm{Bx}=0,974$ yang dapat dinyatakan bahwa setiap penambahan tanggapan responden mengenai Kualitas Produk, maka dapat diikuti oleh keputusan pembelian sebesar $97,0 \%$ atau setiap terjadi peningkatan nilai pada variabel Kualitas Produk sebesar satu point, maka keputusan pembelian akan meningkat sebesar 0,974 poin.
\end{abstract}

Kata kunci: Kualitas, Minat, Penjualan, Produk.

\section{PENDAHULUAN}

Ketatnya persaingan dalam dunia usaha menuntut setiap perusahaan untuk mengambil langkah-langkah dan strategi yang tepat guna memenangkan persaingan dengan kompetitor demi menjaga eksistensi yang dimiliki perusahaan dan tentunya mempertahankan bahkan meningkatkan keuntungan atau profit yang dihasilkan. Tanpa strategi yang tepat perusahaan tidak akan dapat bertahan karena seiring waktu kompetitor akan terus muncul bersamaan dengan permintaan konsumen yang kian meningkat.

Hal ini dihadapi oleh setiap perusahaan yang mencari laba dan tidak terkecuali industri sepeda motor. Saat ini, perkembangan jumlah penduduk yang cukup pesat serta beragamnya aktivitas kerja setiap orang memungkinkan segala aktivitas tersebut harus dilakukan secara cepat. Agar orang dapat melakukan pekerjaan secara cepat, dibutuhkan sarana pendukung, seperti sarana transportasi.

Perusahaan sepeda motor kini memiliki banyak dealer-dealer motor yang menjual sepeda motor dengan berbagai merek. Perusahaan sepeda motor dari berbagai merek tidak berhenti begitu saja untuk terus bersaing dalam menciptakan sepeda motor yang memiliki kualitas lebih baik dan lebih canggih. Bahkan perusahaan juga sering memberikan potongan harga dalam penjualan, potongan harga yang dilakukan perusahaan sering membuat pesaing bisnis penjualan sepeda motor baru semakin meningkat. Penggunaan sepeda motor di Indonesia sangat populer karena harganya yang relatif murah, terjangkau 
untuk sebagian besar kalangan dan penggunaan bahan bakarnya serta serta biaya operasionalnya cukup hemat.

Yamaha Mio masuk sebagai motor terlaris di Indonesia. Yamaha Mio dapat peringkat ke lima dalam penjualan sepeda motor pada tahun 2018 dengan jumlah 1.335 unit yang disaingi oleh empat sepeda motor berupa Honda Beat dengan penjualan sebesar 1604 unit, Honda Vario series dengan penjualan sebesar 1473 unit dan Honda Scoopy dengan penjualan sebesar 1458 unit dan Yamaha Nmax dengan penjualan sebesar 1354.

Persaingan skuter matic yang semakin ketat membuat Yamaha terus terdorong untuk dapat memenuhi kebutuhan dan keinginan para konsumen yang semakin kompleks. Yamaha Mio pertama kali diperkenalkan di Indonesia pada tanggal 22 Juni 2009. Menurut data Asosiasi Industri Sepeda Motor Indonesia (AISI), penjualan Yamaha Mio sepanjang 2018 berhasil menembus angka 254.826 unit untuk seluruh Indonesia. Untuk tetap bertahan pada persaingan yang semakin ketat dalam dunia pemasaran di indonesia.

Yamaha Mio merupakan motor produksi sepeda motor matik pertama yang menggunakan teknologi canggih dan memiliki kualitas produk yang baik maka keinginan konsumen terhadap suatu produk akan terpenuhi. Menurut Handoko (2012) kualitas produk adalah suatu kondisi dari sebuah barang berdasarkan pada penilaian atas kesesuaiannya dengan standar ukur yang telah ditetapkan. Semakin sesuai standar yang ditetapkan maka akan dinilai produk tersebut semakin berkualitas.

Kualitas produk juga merupakan hal penting yang harus diperhatikan oleh setiap perusahaan jika ingin produk yang dihasilkan dapat bersaing di pasar untuk memuaskan kebutuhan dan keinginan konsumen. Kualitas merupakan syarat utama diterimanya suatu produk di pasar. Suatu produk dikatakan berkualitas apabila produk tersebut mampu memenuhi harapan pelanggan. Menurut Kotler Philips (2012). Kualitas produk mempunyai delapan dimensi kualitas yaitu kinerja (performance), fitur (features), kehandalan (reliability), kesesuaian dengan spesifikasi (conformance to specifications), daya tahan (durability), kemampuan layanan (service ability), estetika (aesthetics), dan kualitas yang dirasakan (perceived quality).

Berdasarkan masalah-masalah tersebut di atas, maka peneliti tertarik untuk meneliti lebih lanjut dengan Judul: "Pengaruh Kualitas Produk Terhadap Keputusan Pembelian Kendaraan Bermotor Yamaha Mio pada CV. Rolya Motor di Bandar Lampung".

\section{KAJIAN TEORI}

\section{Pengertian Pemasaran}

Pemasaran merupakan faktor yang penting dalam siklus yang bermula dan berakhir dengan kebutuhan konsumen. Berhasil tidaknya dalam pencapaian tujuan bisnis tergantung pada keahlian di bidang pemasaran. Selain itu juga tergantung pada kemampuan untuk mengkombinasikan fungsi- fungsi tersebut agar dapat berjalan lancar.

Menurut David (2011), "Pemasaran dapat dideskripsikan sebagai proses pendefinisian, pengantisipasian, penciptaan, serta pemenuhan kebutuhan dan keinginan konsumen akan produk dan jasa."

Pemasaran menurut Alma (2015) Pemasaran adalah suatu proses sosial dan manajerial dari individu atau kelompok untuk memenuhi kebutuhan dan keinginannya melalui penciptaan, penawaran, dan pertumbuhan (nilai) produk dengan yang lain. 
Menurut Kotler dan Armstrong dalam Hasibuan (2012), "Marketing as the process by which companies create value for customers and build strong customer relationships in order to capture value from customers in return", artinya menyatakan bahwa pemasaran sebagai proses dimana perusahaan menciptakan nilai bagi pelanggan dan membangun hubungan pelanggan yang kuat untuk menangkap nilai dari pelanggan sebagai imbalan.

\section{Pengertian Manajemen Pemasaran}

Setiap produsen selalu berusaha melalui produk yang dihasilkannya dapatlah tujuan dan sasarannya tercapai. Produk yang dihasilkan dapat terjual atau dibeli oleh konsumen akhir dengan tingkat harga yang memberikan keuntungan perusahaan jangka panjang. Melalui produk yang dapat dijualnya, perusahaan dapat menjamin kehidupannya atau menjaga kestabilan usahanya dan berkembang. Dalam rangka inilah setiap produsen harus memikirkan kegiatan pemasaran produknya, jauh sebelum produk ini dihasilkan sampai produk tersebut di konsumsi oleh si konsumen akhir.

Konsep pemasaran adalah kegiatan perencanaan pemasaran untuk mencapai tujuan perusahaan yaitu kepuasan pelanggan. Segala aktifitas yang menganut konsep pemasaran harus diarahkan untuk memenuhi tujuan tersebut. Pengertian Manajemen Pemasaran menurut Sofjan Assauri (2013), adalah "Manajemen pemasaran merupakan kegiatan penganalisisan, perencanaan, pelaksanaan, dan pengendalian programprogram yang dibuat untuk membentuk, membangun, dan memelihara keuntungan dari pertukaran melalui sasaran pasar guna mencapai tujuan organisasi (perusahaan) dalam jangka panjang".
Pengertian manajemen pemasaran menurut Philip Kotler (2012) "Pemasaran adalah proses sosial dan managerial dengan mana seseorang atau kelompok memperoleh apa yang mereka butuhkan dan inginkan melalui penciptaan dan pertukaran produk dan nilai". Sedangakan Pengertian manajemen pemasaran menurut Kotler dan Armstrong (2012), menyebutkan bahwa : "Manajemen pemasaran adalah analisis, perencanaan, pelaksanaan, dan pengendalian atas program yang dirancang untuk menciptakan, membangun, dan mempertahankan pertukaran yang menguntungkan dengan pembeli sasaran dengan maksud untuk mencapai sasaran organisasi.

\section{Pengertian Produk}

Produk merupakan titik pusat dari kegiatan pemasaran karena produk merupakan hasil dari suatu perusahaan yang dapat ditawarkan ke pasar untuk di konsumsi dan merupakan alat dari suatu perusahaan untuk mencapai tujuan dari perusahaannya. Suatu produk harus memiliki keunggulan dari produk-produk yang lain baik dari segi kualitas, desain, bentuk, ukuran, kemasan, pelayanan, garansi, dan rasa agar dapat menarik minat konsumen untuk mencoba dan membeli produk tersebut.

Produk menurut Kotler, Philip dalam Tjiptono, (2012) adalah sebagai berikut: "Produk adalah segala sesuatu yang dapat ditawarkan ke pasar untuk mendapatkan perhatian, dibeli, digunakan atau dikonsumsi yang dapat memuaskan keinginan dan kebutuhan". Menurut Buchari Alma (2011) pengertian produk adalah sebagai berikut : "Produk ialah seperangkat atribut baik berwujud maupun tidak berwujud, termasuk didalamnya masalah warna, harga, nama baik pabrik, nama baik toko yang menjual (pengecer), dan pelayanan pabrik serta pelanan 
pengecer, yang diterima oleh pembeli guna memuaskan keinginannya". Kemudian Fandy Tjiptono (2010) mendefinisikan produk sebagai berikut : "Produk adalah segala sesuatu yang dapat ditawarkan produsen untuk diperhatikan, diminta, dicari, dibeli, digunakan atau dikonsumsi pasar yang bersangkutan". Dari definisi diatas dapat disimpulkan bahwa produk merupakan segala sesuatu yang dapat ditawarkan kepada pelanggan atau konsumen baik berbentuk sesuatu yang berwujud maupun tidak berwujud yang diciptakan oleh perusahaan untuk memuaskan kebutuhan dan keinginan konsumen.

\section{Kualitas Produk}

Juran dalam (Nasution, 2015). Kualitas produk adalah kecocokan penggunaan produk (fitness for use) untuk memenuhi kebutuhan dan kepuasan Konsumen.

Nasution (2015) kualitas produk adalah suatu kondisi dinamis yang berhubungan dengan produk, manusia/tenaga kerja, proses dan tugas, serta lingkungan yang memenuhi atau melebihi harapan Konsumen atau konsumen.

Tjiptono (2012) mendefinisikan kualitas sebagai tingkat mutu yang diharapkan dan pengendalian keragaman dalam mencapai mutu tersebut untuk memenuhi kebutuhan konsumen.

Berdasarkan definisi diatas dapat disimpulkan bahwa kualitas produk adalah suatu keadaan dimana konsumen merasa cocok dengan suatu produk atau sesuai dengan keinganan yang diharapkan untuk memenuhi kebutuhannya. Menurut Garvin dalam Tjiptono (2012) Kualitas produk mempunyai delapan dimensi kualitas yaitu kinerja, ciri-ciri atau keistimewaan tambahan, kehandalan, kesesuaian, daya tahan, kemampuan layanan, estetika, ketepatan kualitas yang dipersepsikan.

\section{METODE PENELITIAN}

\section{Objek Penelitian}

Penelitian ini dilaksanakan pada CV. Rolya Motor di Lampung yang beralamat di Jalan RA. Kartini No. 126 Tanjungkarang Pusat, Kota Bandar Lampung. Perusahaan ini bergerak dalam bidang perdagangan, yaitu menjual kendaraan bermotor dua roda merk Yamaha. Penelitian dilaksanakan pada bulan Agustus 2019 sampai dengan Oktober 2019.

\section{Metode dan Teknik Pengumpulan Data}

Adapun metode pengumpulan data dalam penelitian ini diperoleh dari data primer dan data sekunder.

1. Data Primer

Data primer yaitu data yang dikumpulka dan diolah langsung dari objek penelitian, seperti catatan, agenda, dokumen, laporan tahunan dan sebagainya.

2. Data Sekunder

Merupakan data yang diperoleh melalui orang lain yang berhubungan dengan permasalahan yang dipecahkan. Data sekunder ini diperoleh melalui cara studi dokumenter yaitu mengumpulkan adn mempelajari brosur-brosur serta dokumen-dokumen, catatan-catatan dan arsip perusahaan.

Teknik pengumpulan data yang penulis gunakan dalam penelitian ini adalah:

1. Observasi

Yaitu mengumpulkan data dengan cara peninjauan langsung ke $\mathrm{CV}$. Rolya Motor Bandar Lampung. 
2. Wawancara

Yaitu dengan cara melakukan wawancara secara langsung terhadap konsumen CV. Rolya Motor.

3. Questioner

Yaitu dengan cara menyebar angket berupa pertanyaan.

4. Dokumentasi

Yaitu mengumpulkan data dengan cara mengkaji catatan, agenda, arsip- arsip dari perusahaan yang berkaitan dengan masalah penelitian ini.

\section{Sampel dan Populasi}

Menurut Nanang Martono (2011) mendefinisikan populasi adalah seluruh objek atau subjek yang berada pada suatu wilayah dan memenuhi syarat-syarat tertentu berkaitan dengan masalah penelitian, atau keseluruhan unit atau individu dalam ruang lingkup yang akan diteliti.

Adapun populasi dalam penelitian ini adalah konsumen CV. Rolya Motor di Bandar Lampung sebanyak 120 orang, kemudian menurut Suharsimi Arikunto (2013) apabila objek penelitian lebih dari 100 maka lebih baik diambil sebagian yang besar 15 hingga 20 persen untuk dijadikan sebagai sampel. Data penjualan yang dijadikan sampel dalam penelitian ini adalah data penjualan bulan Desember dengan jumlah 120 konsumen. Dari 120 konsumen yang dijadikan responden adalah $120 \times 15 \%=18$ orang.

\section{Metode Analisis Data}

Analisis kualitatif yaitu menganalisa permasalahan dengan cara membandingkan antara teori dengan permasalahan yang dihadapi oleh CV. Rolya Motor di Bandar Lampung, yaitu mengenai pembelian kendaraan bermotor.
Dalam menganalisis secara kuantitatif menggunakan rumus statistik yaitu rumus uji linear sederhana sebagai berikut :

$$
Y=a+b X+e
$$

Keterangan:

$\mathrm{Y}=$ Keputusan Pembelian

$\mathrm{a}=$ Konstanta

$\mathrm{b}=$ Koefisien regresi $\mathrm{X}$

$\mathrm{X}=$ Kualitas produk

$\mathrm{e}=$ Faktor kesalahan

Untuk mengetahui besarnya pengaruh, penghitungan koefisien korelasi tersebut kemudian dilanjutkan dengan Rumus Koefisien Determinasi atau Koefisien Penentu (KP):

$$
K P=(r)^{2} x 100 \%
$$

Untuk menguji secara hipotesis secara parsial digunakan Uji t dengan rumus :

$$
t_{\text {hitung }}=\frac{r \sqrt{N-2}}{\sqrt{1-r^{2}}}
$$

Keterangan:

$$
\begin{aligned}
& \mathrm{t}_{\text {hitung }} \quad=\text { Nilai } \mathrm{t} \\
& \mathrm{r} \quad=\text { Koefisien Korelasi } \\
& \mathrm{N} \quad=\text { Jumlah responden }
\end{aligned}
$$

Kriteria untuk Uji $\mathrm{t}$ adalah sebagai berikut :

a) Jika $t_{\text {hitung }}>t_{\text {tabel }}$ maka Ha diterima dan Ho ditolak.

Jika $t_{\text {hitung }} \leq \mathrm{t}_{\text {tabel }}$ maka Ha ditolak dan Ho diterima.

\section{HASIL DAN PEMBAHASAN}

\section{Analisis Kualitatif}

Untuk syarat minimum agar dianggap memenuhi syarat valid adalah dengan 
mengkorelasikan masing-masing dengan skor total variabel. Kemudian angka korelasi yang dihasilkan akan dibandingkan dengan nilai rtabel pada 0,05 dengan df (degre of freedom $)=18$ yaitu sebesar 0,318 .

Dengan demikian berdasarkan uji validitas maka butir dalam instrumen tersebut dinyatakan valid apabila nilai thitung skor item terhadap skor totalnya lebih besar (>) dari 0,318 atau dikatakan tidak valid apabila nilai thitung skor item terhadap sekor totalnya lebih kecil $(<)$ dari 0,318. oleh karenanya, semakin baik nilai koefisien korelasi person suatu item, memperlihatkan semakin baik validitas item tersebut.

Uji Reliabilitas (keterpercayaan) yang dipergunakan adalah untuk mengetahui layak tidaknya data responden yang digunakan dalam penelitian. Untuk uji relaibilitas ini digunakan Teknik Aplha Cronbach, dimana suatu instrumen dikatakan handal (reliabel) bila memiliki koefisien keandalan atau alpha sebesar 0,5 atau lebih (Sugiono, 2003).

Reliabilitas pernyataan variabel kualitas produk ditunjukan pada tabel 12 dengan jumlah responden ( $N$ of Cases) sebesar 18 dan jumlah 10 item pernyataan $(N$ of items) aplha total sebesar 0,795. Dari 10 item pernyataan nilai alpha if item deleted seluruhnya menunjukkan reliabel, karena nilai 10 item pernyataan lebih besar dari 0,672 .

\section{Analisis Kuantitatif}

Persamaan regresi antara variabel Kualitas Produk (X) terhadap variabel keputusan Pembelian (Y) adalah $\mathrm{Y}=$ $0,758+0,974 \mathrm{X}$. Penjelasannya adalah bo $=$ 0,758 merupakan nilai konstanta atau yang dapat diartikan bahwa kualitas produk bernilai konstan, maka bila setiap terjadi peningkatan nilai pada variabel keputusan pembelian sebesar satu poin, berakibat kualitas produk hanya akan meningkat sebesar $0,758 \%$. $\mathrm{Bx}=0,974$ yang dapat dinyatakan bahwa setiap penambahan tanggapan responden mengenai kualitas produk, maka dapat diikuti oleh keputusan pembelian sebesar 97,0\% atau setiap terjadi peningkatan nilai pada $\mathrm{v}$ ariabel keputusan pembelian sebesar satu point, maka keputusan pembelian akan meningkat sebesar 0,974 poin.

Koefisien Determinasi $=\mathrm{R} 2=0,9492$ $=0,901=0,901 \times 100=90,1 \%$. Dapat disimpulkan bahwa variabel kualitas produk menjelaskan variasi perubahan terhadap variabel keputusan pembelian kendaraan bermotor yamaha Mio pada CV. Rolya Motor di Bandar Lampung sebesar 90,1\%, sedangkan sisanya dijelaskan oleh faktor lain yang tidak dikaji dalam penelitian ini.

Berdasarkan hasil Uji $t$ didapat nilai thitung $=12,060$. Apabila dibandingkan dengan ttabel pada taraf signifikan $95 \%$ yaitu 1,73 maka thitung=12,060> ttabel=1,73 sehingga dapat disimpulkan bahwa : Ha yang menyatakan terdapat pengaruh antara variabel Kualitas Produk (X) terhadap Keputusan Pembelian (Y) dapat diterima. Jadi variabel Kualitas Produk (X) berpengaruh terhadap variabel Keputusan Pembelian (Y).

Apabila merujuk dari hasil pembahasan berkenaan dengan pengaruh antara kualitas produk dan keputusan pembelian kendaraan bermotor Yamaha Mio pada CV. Rolya Motor di Bandar Lampung dimana berdasarkan hasil Uji t didapat nilai t hitung $=12,060$ dan setelah dibandingkan dengan $\mathrm{t}$ tabel pada taraf signifikan $95 \%$ yaitu 1,73 , maka $\mathrm{t}$ hitung $=12,060>\mathrm{t}$ tabel $=1,73$ sehingga dapat disimpulkan bahwa: Ha yang menyatakan terdapat pengaruh antara variabel kualitas produk (X) terhadap keputusan pembelian (Y) dapat diterima. 
Jadi variabel kualitas produk (X) berpengaruh terhadap keputusan pembelian (Y). Menurut hemat penulis, besarnya nilai $\mathrm{t}$ hitung $=12,060$ adalah karena kualitas produk ini terkesan lemah dan kalaupun ada pengaruh kualitas produk terhadap keputusan pembelian baru menampakkan peningkatan. Hal ini dibuktikan dengan perhitungan pada Koefisien Determinasi $=\mathrm{R} 2=0,9492=$ $0,901=0,901 \times 100=90,1 \%$.

Dapat disimpulkan bahwa variabel keputusan pembelian menjelaskan variasi perubahan terhadap variabel kualitas produk sebesar $90,1 \%$, dan persamaan regresi antara variabel kualitas produk (X) terhadap variabel keputusan pembelian (Y) adalah $\mathrm{Y}=0,758+0,974 \mathrm{X}$ penjelasannya adalah : bo $=0,758$ merupakan nilai konstanta atau yang dapat diartikan bahwa promosi bernilai konstan, maka bila setiap terjadi peningkatan nilai pada variabel kualitas produk sebesar satu point, berakibat keputusan pembelian hanya akan meningkat sebesar $0,758 \%$.

$\mathrm{Bx}=0,974$ yang dapat dinyatakan bahwa setiap penambahan tanggapan responden mengenai kualitas produk, maka dapat diikuti oleh keputusan pembelian sebesar satu point, maka keputusan pembelian akan meningkat sebesar 0,974 point, artinya kualitas produk akan berjalan baik jika keputusan pembelian baik dan ini akan meningkatkan point sebesar 0,974. Bila kualitas produk baik, maka setidaknya keputusan pembelian kendaraan bermotor Yamaha Mio pada CV. Rolya Motor di Bandar Lampung dapat berjalan dengan baik.

Selanjutnya dalam menguji keberanian dari koefisien korelasi tata jenjang Spearman. Pada taraf kepercayaan sebesar $95 \%$ atau $\alpha=0,05$ diketahui nilai $t_{\text {tabel }}$ adalah 1,753. Besarnya ketentuan bahwa jika hasil t hitung lebih besar dari tabel, maka hipotesis (Ho) ditolak. Hasil perhitungan diperoleh $t_{\text {hitung }}$ lebih besar dari $t_{\text {tabel }}$ pada taraf signifikan sebesar $95 \%$ atau $\alpha=0,05$, maka hipotesis yang menyatakan tidak ada hubungan antara insentif penjualan terhadap produktivitas kerja karyawan penjualan ditolak atau tidak dapat diterima. Ini berarti bahwa ada terdapat hubungan yang positif antara insentif penjualan terhadap produktivitas kerja karyawan penjualan. Hubungan yang ada dinyatakan dengan $r_{\text {ho }}$ yang sangat kuat dan nilainya positif.

\section{KESIMPULAN DAN SARAN}

\section{Kesimpulan}

Dari pembahasan yang telah diuraikan, maka dapat ditarik kesimpulan bahwa $\mathrm{Ha}$ yang menyatakan terdapat pengaruh antara variabel Kualitas Produk (X) terhadap Keputusan Pembelian (Y) dapat diterima. Jadi variabel Kualitas Produk (X) berpengaruh terhadap variabel Keputusan Pembelian (Y). Kualitas Produk bernilai konstan sebesar satu point, berakibat keputusan pembelian akan meningkat sebesar $0,758 \%$. $\mathrm{Bx}=0,974$ yang dapat dinyatakan bahwa setiap penambahan tanggapan responden mengenai Kualitas Produk, maka dapat diikuti oleh keputusan pembelian sebesar $97,0 \%$ atau setiap terjadi peningkatan nilai pada variabel Kualitas Produk sebesar satu poin, maka keputusan pembelian akan meningkat sebesar 0,974 poin.

\section{Saran}

Berdasarkan kesimpulan yang telah dikemukakan diatas maka, maka penulis dapat memberikan saran sebagai berikut :

1. Hendaknya kualitas produk yang ditawarkan oleh CV. Rolya Motor khusus kendaraan bermotor Yamaha Mio semakin baik lagi. 
2. Hendaknya pihak CV. Rolya Motor dapat memberikan pelayanan yang maksimal sehingga keputusan pembelian kendaraan bermotor Yamaha Mio akan semakin meningkat setiap tahunnya.

\section{DAFTAR PUSTAKA}

Alma. 2015. Manajemen pemasaran dan Pemasaran Jasa. Bandung: Alfabeta.

Arikunto, Suharsimi. 2012. Prosedur Penelitian Suatu Pendekatan Praktik. Jakarta: PT.Rineka.

Fandy, Tjiptono. 2010. Pemasaran Jasa. Malang: Bayupedia Publising.

Hadi, Sutrisno. 2013. Metode Penelitian. Yogyakarta: BPFE-UGM.

Hasibuan. 2013. Manajemen Sumber Daya manusia. Jakarta: Bumi Aksara.

Kotler, Amstrong. 2012. Perilaku Konsumen. Jakarta: Prenbalillido.

Martono. 2011. Metode Penelitian Kuantitatif. Jakarta: PT Raya.

Nasution. 2015. Kualitas Produk. Bogor: Ghalia Indonesia.

Sciffman, Kanuk. 2012. Perilaku Konsumen. Jakarta: PT. Indeks Gramedia.

Setiadi. 2010. Perilaku Konsumen. Jakarta: Kencana.

Sofjan, Assauri. 2013. Manajemen Pemasaran. Jakarta: Rajawali Pers.

Sumarwan. 2014. Perilaku konsumen dan Penerapan dalam Pemasaran. Bogor: Ghalia Indonesia.
Tjiptono. 2010. Strategi Pemasaran Edisi

2. Yogyakarta: Andi Offiset.

Tjiptono. 2012. Prinsip - Prinsip Pemasaran. Yogyakarta: Andi Offset. 